J. Appl. Glycosci., 52, 85-93 (2005)

(C) 2005 The Japanese Society of Applied Glycoscience

\title{
Effects of Soaking and High-Pressure Treatment on the Qualities of Cooked Rice
}

(Received September 27, 2004 ; Accepted Jannuary 10, 2005)

\author{
Miho Yamakura, ${ }^{1, *}$ Kazutomo Haraguchi, ${ }^{2}$ Hiroshi Okadome, ${ }^{2}$ Keitaro Suzuki, ${ }^{2}$ Uyen Thi Tran, \\ Akemi K. Horigane, ${ }^{2}$ Mitsuru Yoshida, ${ }^{2}$ Seiichi Homma, ${ }^{1}$ Akihiko Sasagawa, ${ }^{3}$ \\ Akira Yamazaki ${ }^{3}$ and Ken'ichi Ohtsubo ${ }^{1,2}$
}
${ }^{1}$ Graduate School of Humanities and Sciences, Ochanomizu University (2-1-1, Otsuka, Bunkyo-ku, Tokyo 112-8610, Japan)
${ }^{2}$ National Food Research Institute (2-1-12, Kannondai, Tsukuba 305-8642, Japan)
${ }^{3}$ Research Institute, Echigo Seika Co., Ltd. (1003-1, Takanashi-machi, Ojiya 947-0102, Japan)

\begin{abstract}
In this study, changes in rice qualities from High-Pressure (HP) treatment were investigated. Milled rice grains were presoaked in water at 25 and $55^{\circ} \mathrm{C}$ for 30 min, subjected to HP treatment at 400 MPa for 10 min, and soaked in water overnight. The effects of presoaking temperature and HP treatment on the physical and chemical properties of rice were evaluated. The viscosities of milled rice grains increased with the soaking process. The total sugar content increased and change in the internal structure of the rice grains occurred after HP treatment. The structural change seemed to promote the water penetration and brought about a higher degree of swelling in rice granules, which might result in a higher degree of gelatinization and higher digestibility of HP-treated cooked rice. HP treatment also brought about denaturation of water soluble proteins and an increase in some free amino acids. HP processing was thus proved to be one of the advantageous processing methods for cooked rice with better palatability.
\end{abstract}

Key words: high pressure, rice, gelatinization, NMR imaging, digestibility

Recently high pressure (HP) technology has been recognized to be very useful in the food industry. ${ }^{1)}$ Numerous studies were carried out about effects of HP treatment on microbial physiology and control of enzymatic reaction related to sterilization and food processing. ${ }^{1,2)}$ There were, however, only a few reports on HP-treated rice in spite of its importance as an energy and protein source. The application of HP treatment to indica rice grains changed their cooking properties as well as enzymatic treatments. ${ }^{3)}$ Indica rice grains usually have a low gelatinization degree of starch, and their palatability is not suitable for Japanese consumers. Therefore, HP treatment can be applied to the production of cooked indica rice, which would be acceptable for Japanese customers. The combination of HP and protease treatments would be effective for the removal of allergenic proteins from rice grains. ${ }^{4)}$ Gamma aminobutyric acid (GABA) as a bio-function in brown rice was increased by HP treatment. ${ }^{5)}$ Yamazaki et al. have reported that water molecules effectively penetrate into the peripheral portion of each starch granule in rice grains with the HP treatment. ${ }^{6}$

In Japan, consumers currently tend to make much of palatability in the selection of rice. In addition to home cooking, aseptic cooked rice sold in markets has become popular due to the change in life-style. Recently, cooked rice has become an especially important food for the aging society. With this background, we tried to produce safe and palatable aseptic cooked rice by HP treatment after soaking.

*Corresponding author (Tel. +81-258-83-3288, Fax. +81-25883-4479, E-mail: m-yamakura@echigoseika.co.jp).
Soaking is considered to be an essential process for cooking rice with increasing palatability. Rice grains were often soaked in water overnight and cooked the next morning in Japan. Long-time soaking improves the taste of the cooked rice, probably affecting the components in the grains. The most important component in rice is starch. It was reported that properties of starch are deeply related to the palatability of rice. ${ }^{78}$ Rice proteins, which are superior to other proteins in terms of amino acid composition among cereals, are also important components for the palatability of cooked rice. ${ }^{9,10}$ Sugars and free aminoacids in rice are involved in estimation of taste. ${ }^{11)}$

In this study, we investigate the effects of soaking and HP treatment on the rice qualities by measuring pasting properties, sugar and free amino acid contents, enzyme activities, and protein solubility using low-amylose, medium-amylose and high-amylose rice. The internal structural change of grains by HP treatment was discussed in relation to degree of gelatinization and digestibility of the cooked rice.

\section{MATERIALS AND METHODS}

Rice samples. Mature seeds of non-glutinous rice (Oryza sativa L.) cultivars, Milky Queen (Japonica, lowamylose rice), Koshihikari (Japonica, high-quality rice) and Hamasari (Indica, high-amylose rice), were used. Milky Queen was grown in Ibaraki Prefecture, Japan in 2001, Koshihikari in Niigata Prefecture, Japan in 2002, and Hamasari in Saitama Prefecture, Japan in 2002. The samples were stored at low temperature $\left(1-3^{\circ} \mathrm{C}\right)$ before use. Brown rice grains were milled to the milling yield of 
90\% with a TM-05 Grain Testing Mill (SATAKE, Hiroshima, Japan).

High-Pressure (HP) treatment. After removal of broken grains, $20 \mathrm{~g}$ of whole grains were put into a polyethylene film bag together with $30 \mathrm{~mL}$ distilled water. The sample was vacuum-packaged and kept at 25 or $55^{\circ} \mathrm{C}$ for $30 \mathrm{~min}$. The sample was then treated at $400 \mathrm{MPa}$ for 10 min in a HP machine (Ishikawajima-Harima Heavy Industries Co., Ltd., Tokyo, Japan). On the other hand, a "nonHP sample" was kept for at 25 or $55^{\circ} \mathrm{C}$ for $15 \mathrm{~min}$ and stored in a refrigerator at $1-3^{\circ} \mathrm{C}$ overnight.

Preparation of cooked rice sample. The soaked rice grains with water were put into an aluminum cup and kept at room temperature for $30 \mathrm{~min}$. The sample was cooked in an electric rice cooker (SR-ULH18, National Co., Ltd., Osaka, Japan) and kept warm in the cooker for $15 \mathrm{~min}$. Ten grams of cooked rice were frozen rapidly with liquid nitrogen and then lyophilized.

Preparation of rice flour sample. The soaked rice grains were lyophilized and ground into flour with a $\mathrm{Cy}-$ clone sample mill (UDY Corp., Ft. Collins, Colorado, USA). Dried cooked rice grains and intact rice grains were ground into flour, too.

Chemical analysis. The amylose content of the samples was measured by the Juliano method. ${ }^{12)}$ The total sugar of cooked rice samples was measured by the phenol-sulphuric acid method. ${ }^{13)}$ The reducing sugar of cooked rice was measured by the method of SomogyiNelson ${ }^{14)}$ using glucose as a standard. Free amino acid contents were measured by the method of Saikusa et al. ${ }^{15)}$ Free amino acids were extracted from $0.5 \mathrm{~g}$ of flour from intact rice grains or treated cooked rice with $5.0 \mathrm{~mL}$ of sulfosalicylic acid (2\%) and then centrifuged. The supernatant was filtered through a $0.45 \mu \mathrm{m}$ filter (GL chromato-disk 25A, GL Science Co., Ltd. Japan). The prepared sample solution $(10 \mu \mathrm{L})$ was analyzed by an amino acid analyzer (Hitachi 8500, Tokyo, Japan). Nitrogen content of the samples was measured by the combustion method using a LECO System (LECO FP-528, LECO Corporation, Michigan, USA) using EDTA (LECO Corporation) as a standard.

Enzyme activity assay. Protease activity was measured by the method of Palmiano and Juliano ${ }^{16)}$ with minor modifications. The rice grains were separated from soaking water by centrifugation after the HP treatment. The soaked rice grains were homogenized with a homogenizer (ULTRA-TURRAX TP 18-10, Yamamoto Scientific Co., Ltd., Tokyo, Japan) for $20 \mathrm{~s}$ with sodium phosphate buffer ( $\mathrm{pH}$ 7.5) containing $5 \mathrm{~mm}$ cysteine. The homogenate was centrifuged at $5000 \mathrm{rpm}$ at $0^{\circ} \mathrm{C}$ for $15 \mathrm{~min}$ after incubation for $10 \mathrm{~min}$ at room temperature. The supernatant was used for the measurement of protease activity of soaked rice. The sample solution $(0.1 \mathrm{~mL})$ was incubated with $1.0 \mathrm{~mL}$ of $1 \%$ bovine albumin (Wako Pure Chemical Com., Kyoto, Japan) aqueous solution and $1.0 \mathrm{~mL}$ of 0.2 M sodium phosphate buffer $(\mathrm{pH} 6.5)$ at $40^{\circ} \mathrm{C}$ for $90 \mathrm{~min}$. The reaction was stopped by adding $1.0 \mathrm{~mL}$ of $20 \%$ trichloroacetic acid, and the reaction mixture was kept for $1 \mathrm{~h}$ on ice. It was then centrifuged at $8000 \mathrm{rpm}$ at $4^{\circ} \mathrm{C}$ for $15 \mathrm{~min}$. The supernatant was kept at room temperature for $10 \mathrm{~min}$, and the absorbance at $280 \mathrm{~nm}$ was measured.
One unit of protease activity was expressed as the amount of enzyme that increase absorbance of the solution as 0.1 under the conditions of assay. $\alpha$-Amylase and $\beta$-amylase activities were determined using the kits of Megazyme International Ireland, Ltd. (Wicklow, Ireland). $\alpha$-Glucosidase activity was measured according to the method reported by Imai $e$ e $a l .{ }^{17)}$ and Iwata $e t a l .{ }^{18)}$

Pasting properties. Pasting properties of soaked and intact rice flours were measured using a RVA (RapidVisco-Analayzer, New-port Science Ltd., Sydney, Australia) by the method of Toyoshima et al. ${ }^{8}$

Starch digestibility of cooked rice. Starch digestibility was measured by the method of Niihara and Miyoshi ${ }^{19}$ with minor modifications. The cooked rice was cooled down to $40^{\circ} \mathrm{C}$ at room temperature. Ten grams of cooked rice were homogenized with a homogenizer for $1 \mathrm{~min}$ in $90 \mathrm{~mL}$ water, and the $\mathrm{pH}$ was adjusted to 2.0. The sample was incubated at $37^{\circ} \mathrm{C}$ for $30 \mathrm{~min}$ with the addition of 2.5 $\mathrm{mL}$ of pepsin (Sigma-Aldrich Co., St. Louis, USA) solution $(100 \mathrm{mg} / \mathrm{mL})$. The $\mathrm{pH}$ of the solution was then adjusted to 7.1 at $37^{\circ} \mathrm{C}$, and $0.1 \mathrm{~mL}$ aliquots were analysed. The residue was then incubated at $37^{\circ} \mathrm{C}$ for 35 min with the addition of $2.5 \mathrm{~mL}$ of pancreatin $(360 \mathrm{mg} / 12 \mathrm{~mL})$, and $1.0 \mathrm{~mL}$ aliquots were analysed after incubation for 5 , 15,30 and $60 \mathrm{~min}$.

Degree of starch gelatinization of cooked rice. Degree of starch gelatinization was measured by the method of Kainuma et al. ${ }^{20)}$ using dried cooked rice flour as samples.

Nuclear Magnetic Resonance (NMR) micro imaging. NMR micro imaging was performed by the method of Horigane $e t$ al. ${ }^{21}$ Soaked raw rice grains and cooked rice grains were used as samples.

Preparation of gel electrophoresis sample. For water soluble protein analysis, the HP treated sample was homogenized for $1 \mathrm{~min}$ and centrifuged at $5000 \mathrm{rpm}$ at $4^{\circ} \mathrm{C}$ for $20 \mathrm{~min}$. The supernatant was filtered and freeze-dried. The sample was dissolved in water, and centrifuged. The supernatant was lyophilized again, and then dissolved in $0.5 \mathrm{~mL}$ of water. The solutions $(0.05 \mathrm{~mL})$ were mixed with Lysis buffer $(0.1 \mathrm{~mL})$ and subjected to 2D-PAGE, as described by Hirano. ${ }^{22)}$

Electrophoresis. Isoelectric focusing (IEF) gels were prepared as described by O'Farrell. ${ }^{23)}$ Water soluble protein samples were used, $0.05 \mathrm{~mL}$ per glass tube. The sodium dodecyl sulphate (SDS)-PAGE was performed by the method of Laemmli ${ }^{24)}$ with $17 \%$ separation gels and $5 \%$ stacking gels. A molecular weight marker kit (Perfect Protein Markers 10-225 kDa, Novagon Co., Ltd.) was used as standard proteins. After electrophoresis, a part of the gels were stained with Coomassie Brilliant Blue R250 (CBB).

\section{RESULTS AND DISCUSSION}

In this study, we used low-amylose (Milky Queen), medium-amylose (Koshihikari) and high-amylose (Hamasari) rices as samples. Table 1 summarizes the amylose content and pasting property of the rices. The maximum viscosity, minimum viscosity and final viscosity increased significantly with soaking, and differed $(p<0.05)$ from 
Table 1. Amylose content, particle size and pasting properties of intact and processed rice flours.

\begin{tabular}{|c|c|c|c|c|c|c|c|c|c|c|}
\hline & & \multirow{2}{*}{$\begin{array}{l}\text { Presoaked } \\
\text { temp. } \\
\text { ('C) }\end{array}$} & \multirow{2}{*}{$\begin{array}{c}\text { Amylose } \\
(\%)\end{array}$} & \multicolumn{2}{|c|}{ Particle size } & \multicolumn{5}{|c|}{ Pasting properties } \\
\hline & & & & $\begin{array}{l}\text { Average } \\
(\mu \mathrm{m})\end{array}$ & $\begin{array}{c}\text { Under } \\
200 \mu \mathrm{m}(\%)\end{array}$ & $\begin{array}{l}\text { Max. Visc. } \\
\text { (RVU) }\end{array}$ & $\begin{array}{l}\text { Min. Visc. } \\
\text { (RVU) }\end{array}$ & $\begin{array}{l}\text { Breakdown } \\
\text { (RVU) }\end{array}$ & $\begin{array}{c}\text { Final Visc. } \\
\text { (RVU) }\end{array}$ & $\begin{array}{c}\text { Setback } \\
\text { (RVU) }\end{array}$ \\
\hline \multirow{5}{*}{ Milky Queen } & Intact milled rice & - & $8.3 \pm 0.07$ & $175.5^{\mathrm{a}}$ & 68.9 & $327.0^{\mathrm{a}}$ & $115.4^{\mathrm{a}}$ & $214.3^{\mathrm{a}}$ & $185.9^{\mathrm{a}}$ & $69.7^{\mathrm{a}}$ \\
\hline & non-HP & 25 & $8.4 \pm 0.07$ & $116.3^{b}$ & 86.1 & $431.0^{\mathrm{b}}$ & $135.0^{\mathrm{b}}$ & $295.9^{\mathrm{b}}$ & $209.8^{\mathrm{b}}$ & $74.8^{\mathrm{b}}$ \\
\hline & non-HP & 55 & $8.4 \pm 0.14$ & $119.6^{\mathrm{b}}$ & 82.9 & $450.8^{c}$ & $137.2^{\mathrm{c}}$ & $313.5^{\mathrm{c}}$ & $215.1^{\mathrm{c}}$ & $77.9^{c}$ \\
\hline & HP & 25 & $9.0 \pm 0.21$ & $146.7^{\circ}$ & 71.0 & $405.9^{d}$ & $119.2^{\mathrm{a}}$ & $286.2^{\mathrm{d}}$ & $191.4^{\mathrm{d}}$ & $72.1^{\mathrm{b}}$ \\
\hline & HP & 55 & $8.2 \pm 0.00$ & $169.9^{\mathrm{a}}$ & 66.5 & $397.3^{\mathrm{e}}$ & $126.3^{\mathrm{d}}$ & $270.9^{\mathrm{e}}$ & $200.9^{\mathrm{e}}$ & $74.6^{\mathrm{d}}$ \\
\hline \multirow{5}{*}{ Koshihikari } & Intact milled rice & - & $17.5 \pm 0.07$ & $180.3^{\mathrm{a}}$ & 66.9 & $322.6^{\mathrm{a}}$ & $113.7^{\mathrm{a}}$ & $209.4^{\mathrm{a}}$ & $208.6^{\mathrm{a}}$ & $95.1^{\mathrm{a}}$ \\
\hline & non-HP & 25 & $17.7 \pm 0.21$ & $120.0^{\mathrm{b}}$ & 83.3 & $407.3^{\mathrm{b}}$ & $148.9^{b}$ & $258.5^{\mathrm{b}}$ & $261.6^{\mathrm{b}}$ & $112.7^{\mathrm{b}}$ \\
\hline & non-HP & 55 & $17.6 \pm 0.42$ & $119.6^{\mathrm{b}}$ & 83.2 & $419.5^{c}$ & $151.8^{\mathrm{b}}$ & $267.7^{\mathrm{c}}$ & $267.3^{\mathrm{b}}$ & $115.5^{\mathrm{c}}$ \\
\hline & $\mathrm{HP}$ & 25 & $17.8 \pm 0.07$ & $131.9^{c}$ & 79.8 & $384.3^{\mathrm{d}}$ & $139.7^{\mathrm{c}}$ & $243.8^{\mathrm{d}}$ & $248.4^{c}$ & $108.7^{\mathrm{d}}$ \\
\hline & HP & 55 & $17.6 \pm 0.28$ & $145.1^{\mathrm{d}}$ & 72.7 & $379.3^{\mathrm{d}}$ & $136.1^{\mathrm{c}}$ & $236.8^{\mathrm{e}}$ & $246.0^{c}$ & $112.5^{\mathrm{b}}$ \\
\hline \multirow{5}{*}{ Hamasari } & Intact milled rice & - & $28.8 \pm 0.28$ & $131.3^{\mathrm{a}}$ & 78.7 & $209.4^{\mathrm{a}}$ & $134.4^{\mathrm{a}}$ & $72.5^{\mathrm{a}}$ & $304.6^{\mathrm{a}}$ & $171.7^{\mathrm{a}}$ \\
\hline & non-HP & 25 & $28.6 \pm 0.21$ & $119.0^{\mathrm{b}}$ & 82.2 & $284.0^{\mathrm{b}}$ & $172.2^{\mathrm{b}}$ & $111.8^{\mathrm{b}}$ & $381.5^{\mathrm{b}}$ & $209.3^{\mathrm{b}}$ \\
\hline & non-HP & 55 & $28.2 \pm 0.43$ & $121.0^{\mathrm{b}}$ & 82.5 & $281.5^{\mathrm{c}}$ & $180.4^{c}$ & $101.1^{\mathrm{c}}$ & $395.8^{c}$ & $215.4^{c}$ \\
\hline & $\mathrm{HP}$ & 25 & $26.6 \pm 0.14$ & $129.2^{c}$ & 77.7 & $259.4^{\mathrm{d}}$ & $161.2^{\mathrm{d}}$ & $97.9^{\mathrm{d}}$ & $373.9^{\mathrm{d}}$ & $216.8^{d}$ \\
\hline & HP & 55 & $28.4 \pm 0.36$ & $137.4^{\mathrm{d}}$ & 75.1 & $234.4^{\mathrm{e}}$ & $172.3^{\mathrm{b}}$ & $62.3^{\mathrm{e}}$ & $368.9^{\mathrm{e}}$ & $196.7^{\circ}$ \\
\hline
\end{tabular}

Mean value \pm SD $(n=3)$. Different letters in the same column indicate significant difference $(p<0.05)$.

those of the intact rices, except for minimum viscosity in HP-Milky Queen at $25^{\circ} \mathrm{C}$. HP-Treated rices had lower maximum viscosity than non-HP rices. The maximum viscosity and breakdown of Koshihikari (medium-amylose) were lower than those of Milky Queen (low-amylose), but higher than that of Hamasari (high-amylose). It was reported that rice cultivars with high palatability showed high values in the maximum viscosity and break down in pasting properties. ${ }^{25}$ The results obtained in RVA analysis suggested that the eating quality of rice was improved by soaking. The minimum viscosity and final viscosity of Koshihikari (medium-amylose) were higher than those of Milky Queen (low-amylose), but lower than those of Hamasari (high-amylose). HP-Treated rices had lower minimum and final viscosity than those of non-HP rices. The minimum viscosity might be related to retrogradation. ${ }^{26)}$ The results suggested that HP-treatment improved retrogradation of cooked rice.

Table 1 summarizes the particle size of the flour sample. The difference between pre-soaked samples and the intact ones was marked in each cultivar, and was significantly different $(p<0.05)$ from those of the intact rice, except for in HP-Milky Queen at $55^{\circ} \mathrm{C}$. In Milky Queen and Koshihikari, the rate of the particle diameter $200 \mu \mathrm{m}$ in intact milled rice was lower than in pre-soaked samples except for in HP-Milky Queen at $55^{\circ} \mathrm{C}$. High amylose rice particles were smaller than for other cultivars, ${ }^{27)}$ and same result in our study. It was reported that maximum viscosity of the large size particle was lower than for the small size one in amylogram. ${ }^{28}$ Maximum viscosity in RVA (Table 1) and particle size of flour changed with soaking. However, no correlation $(r=-0.074)$ between maximum viscosity in RVA and particle size of flour.

Total sugar increased with the soaking at $55^{\circ} \mathrm{C}$ and $\mathrm{HP}$ treatment, and significantly differed $(p<0.05)$ from those of the non-HP at $25^{\circ} \mathrm{C}$ (Fig. 1A). Milky Queen had the largest amount of total sugar and decreased in the order of Hamasari and Koshihikari. Reducing sugar increased with HP treatment at $25^{\circ} \mathrm{C}$, the difference of which was small with that of the non-HP treated sample (Fig. 1B). Ha-
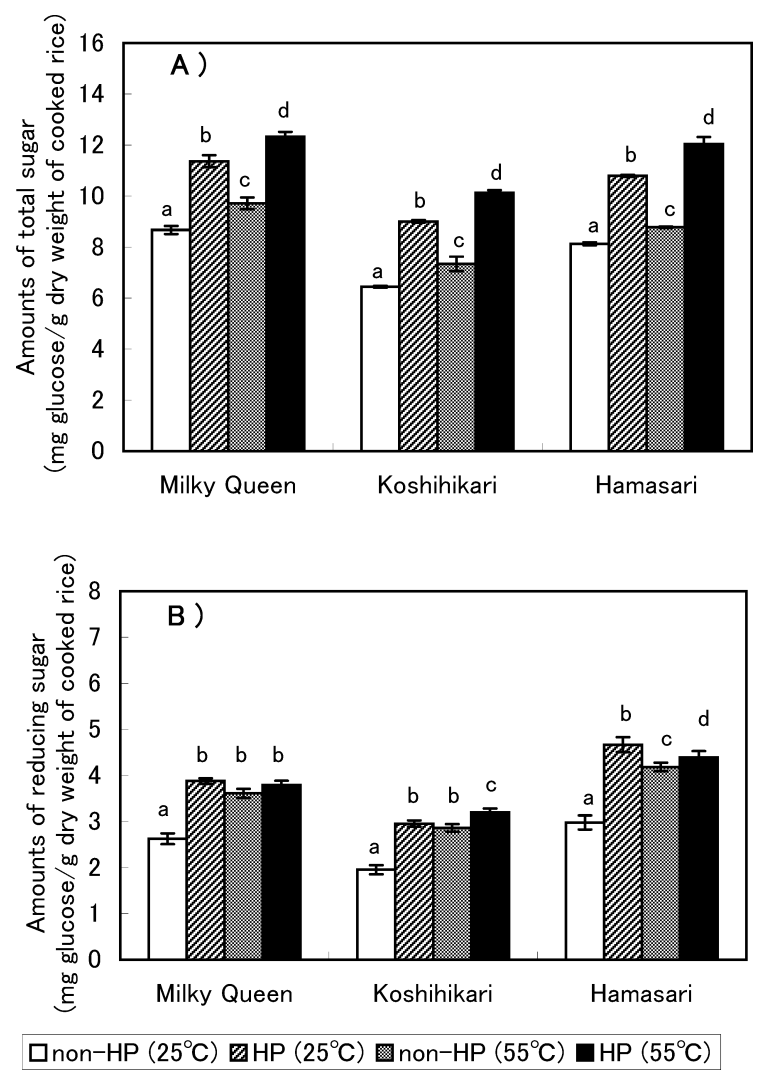

Fig. 1. Total sugar and reducing sugar in the cooked rice.

A) Amount of total sugar, B) Amount of reducing sugar. Different letters in the same cultiver indicate significant difference $(p<$ $0.05)$.

masari had the largest amount of reducing sugar, followed by Milky Queen and Koshihikari. The result suggested that total and reducing sugar contents were not related to amylose content, but to HP treatment $(p<0.01)$. The results suggested that change in the enzyme activity in the rice grains was caused by the HP-treatment.

$\alpha$-Amylase activity was highest in the intact milled rice for all cultivars, but decreased with soaking and HPtreatment (Fig. 2A). On the other hand, $\beta$-amylase activity was detected after HP treatment and soaking in Milky 

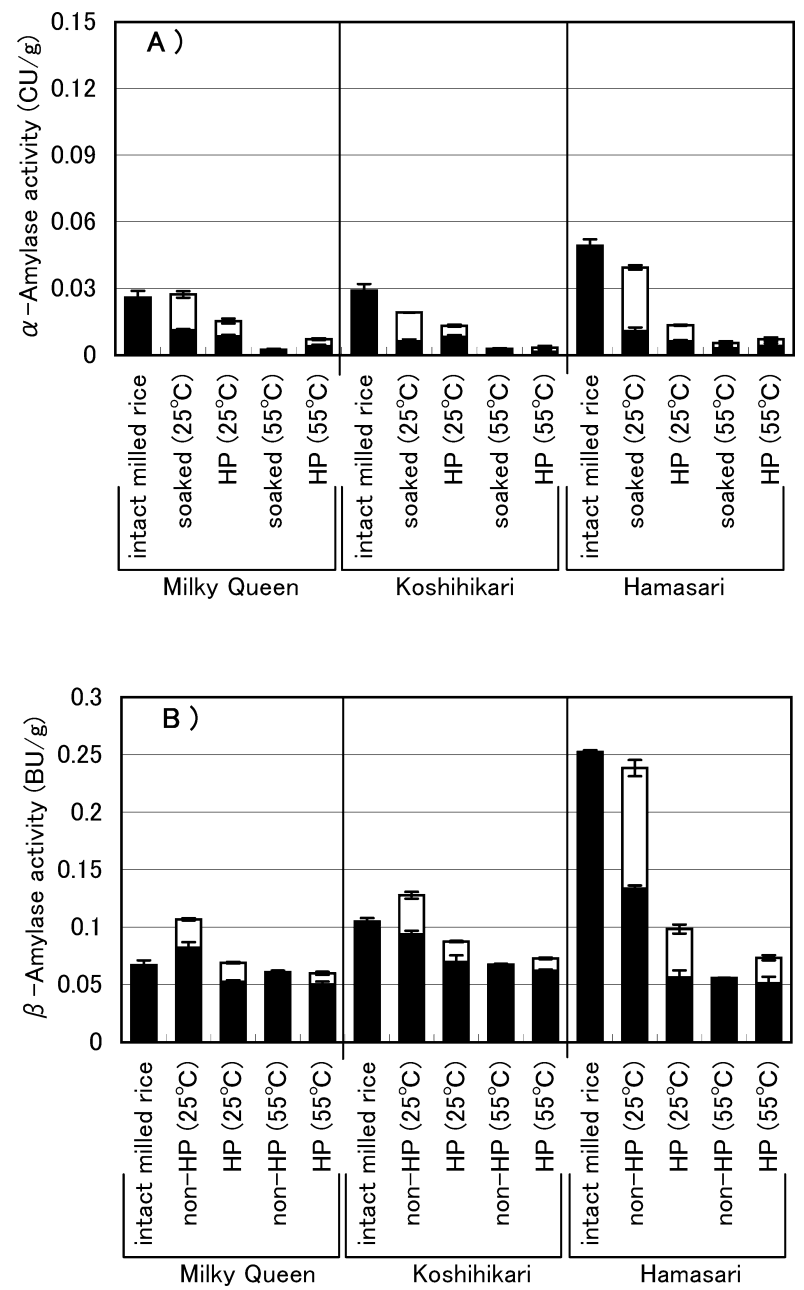

Fig. 2. Amylase activity in the rice grains and soaking solution.

A) $\alpha$-Amylase activity, B) $\beta$-Amylase activity. CU, ceralpha units; BU, betamyl units. $\mathbf{\square}$, rice grains; $\square$, soaking solution.

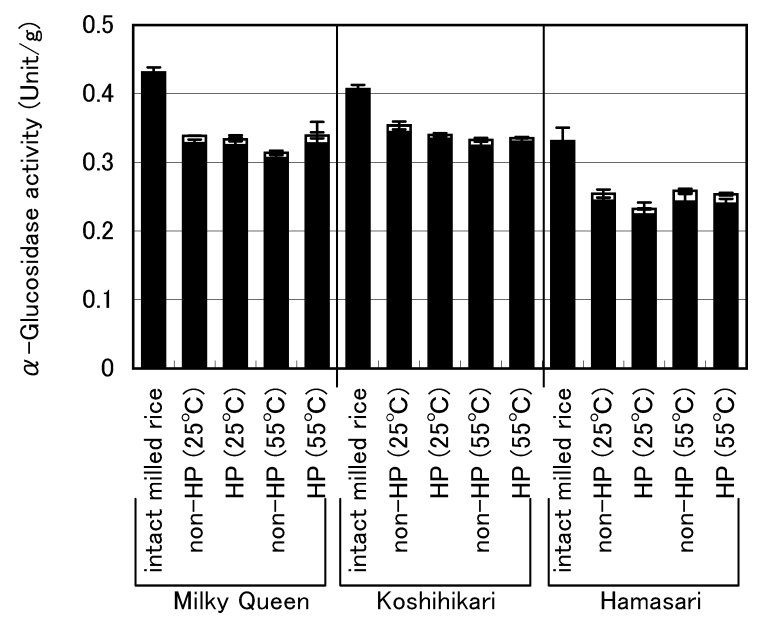

Fig. 3. $\alpha$-Glucosidase activity in the rice grains and soaking solution.

$\mathbf{\square}$, rice grains; $\square$, soaking solution.

Queen and Koshihikari (Fig. 2B) and showed a little high activity even after soaking or HP treatment at $55^{\circ} \mathrm{C}$. This may be due to one of the $\beta$-amylases having a characteristic of high temperature resistance. ${ }^{29)} \beta$-Amylase in highamylose rice (Hamasari) showed high activity as well as that of $\alpha$-amylase.

As shown in Fig. 3, $\alpha$-glucosidase activity of Milky
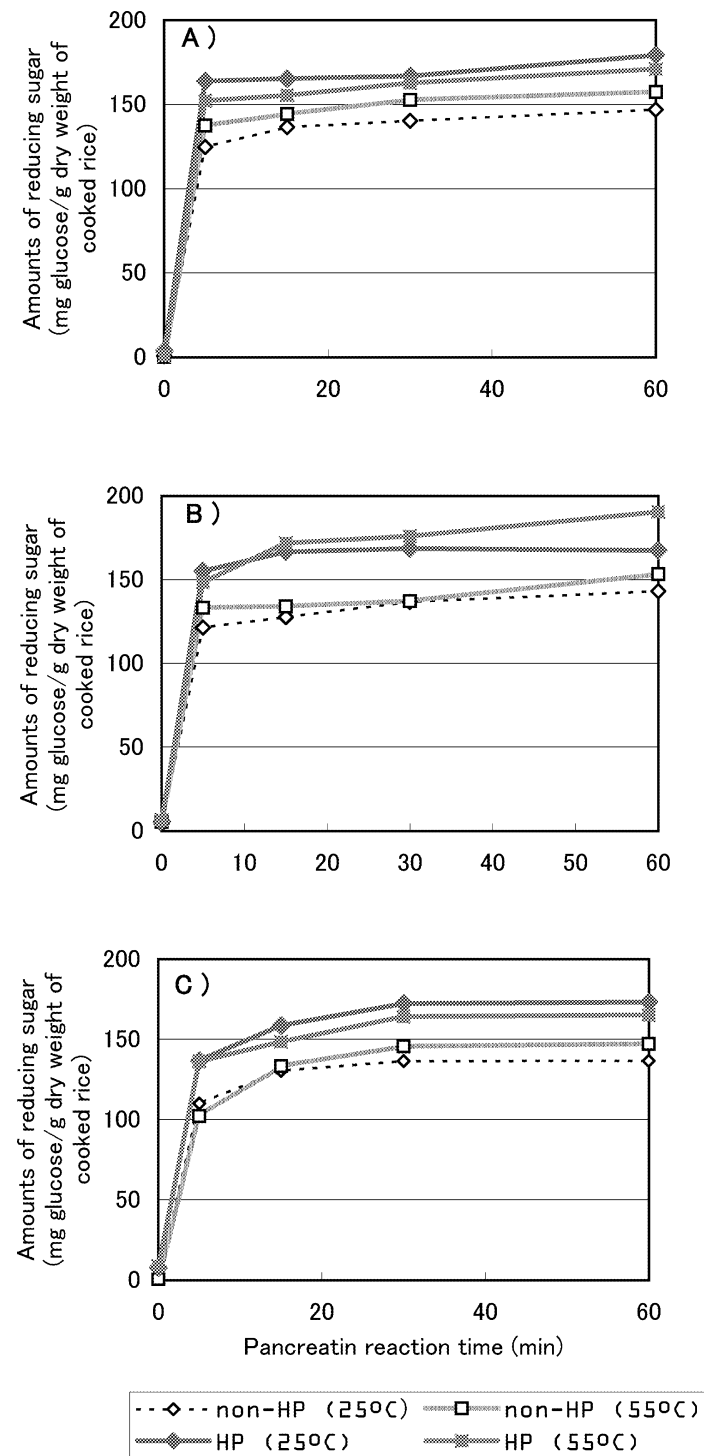

Fig. 4. Starch digestibility of cooked rice.

A) Milky Queen, B) Koshihikari, C) Hamasari.

Queen and Koshihikari was higher than that of Hamasari. $\alpha$-Glucosidase activity of intact milled rice was highest for each cultivar. The activity decreased a little with soaking but maintained almost the same value even after HP treatment. It was reported that $\alpha$-glucosidase activity was detected even during the cooking process, ${ }^{30)}$ and it had activity at a high optimum temperature. ${ }^{31)}$ The tolerance of $\alpha$-glucosidase activity might lead to an increase in the low-molecular weight sugars, such as glucose and maltose, during presoaking and HP treatment. Masui reported that the $\alpha$-glucosidase activity increased with HP treatment when milled rice flour was used. ${ }^{32)}$ However, $\alpha$ glucosidase activity after HP treatment was smaller than that of intact milled rice in our experiment.

Figure 4 shows the results of the starch digestibility test of cooked rice. HP treatment increased starch digestibility for all cultivars. In Milky Queen and Koshihikari, reducing sugar content after 5 min digestion reached about 80$90 \%$ for $60 \mathrm{~min}$ digestion. With HP treatment, more reducing sugars were generated by pancreatin digestion. In Hamasari, reducing sugar content after $5 \mathrm{~min}$ digestion was about $70-80 \%$ for $60 \mathrm{~min}$ digestion. The lowest di- 
Table 2. Degree of gelatinization of starch and protein contents of samples.

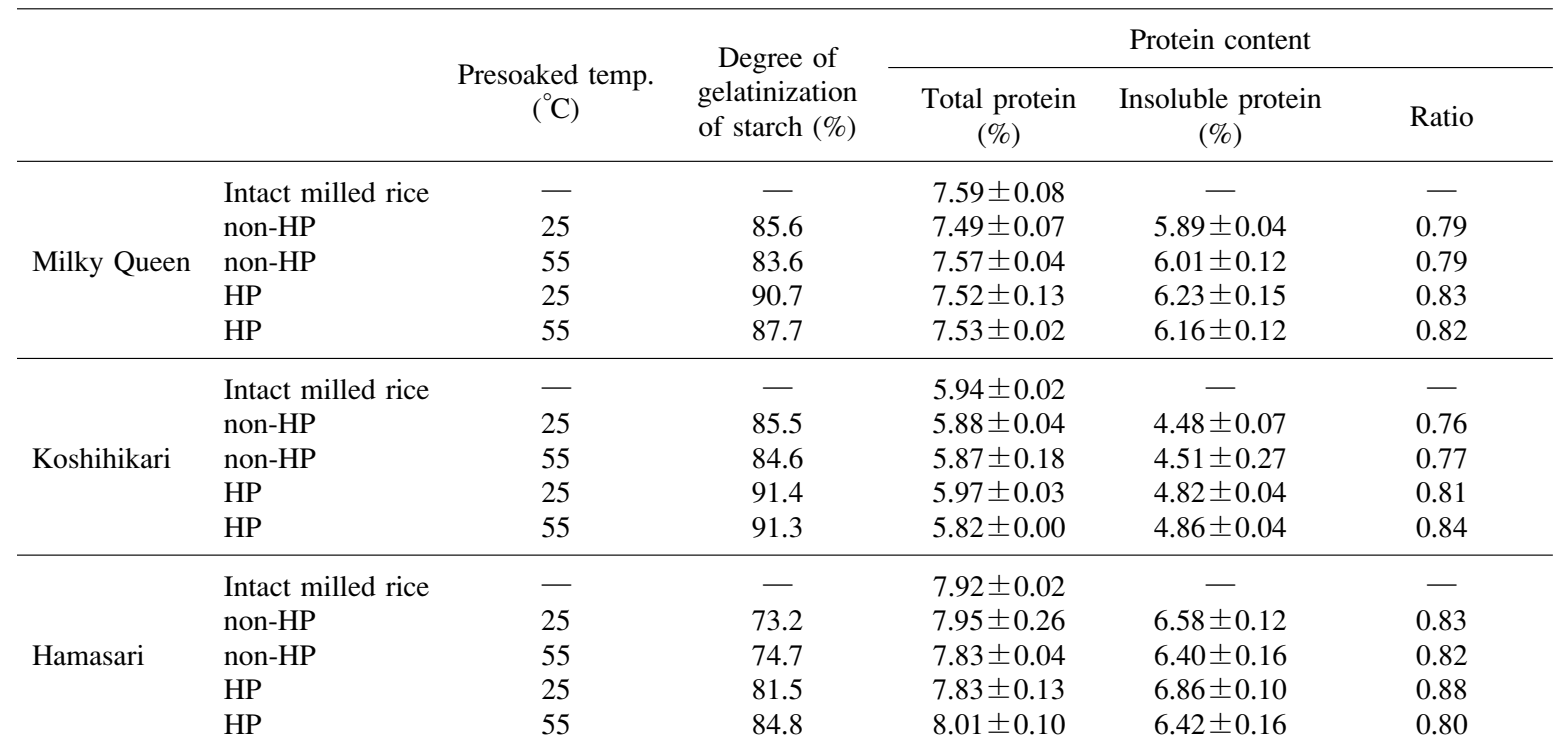

Mean value $\pm \operatorname{SD}(n=3)$. Ratio: Insoluble protein/Total protein.
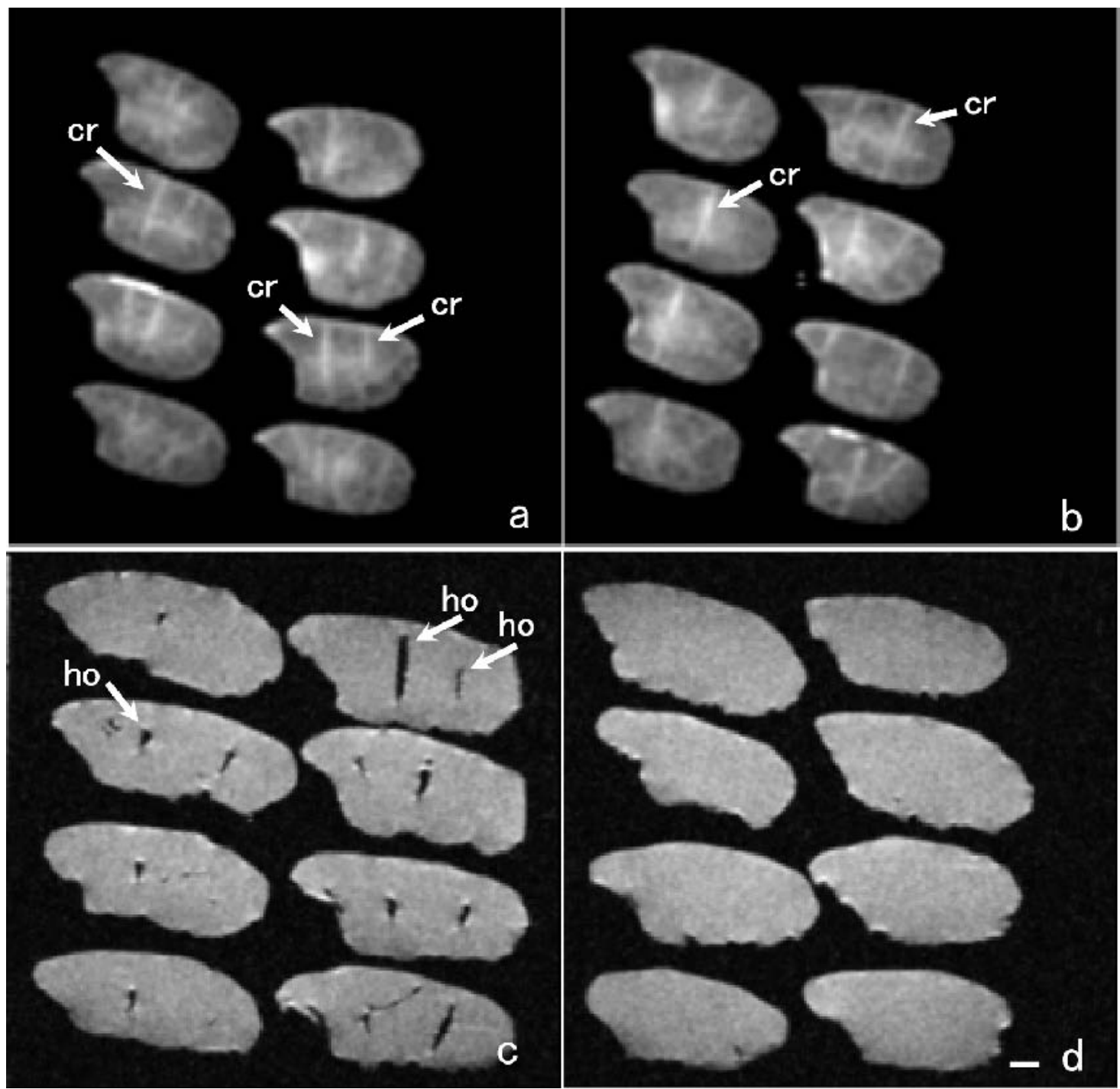

Fig. 5. NMR micro images of raw and cooked rice grains of cv. Koshihikari.

a, raw rice grains (non-HP); b, raw rice grains (HP); c, cooked rice grains (non-HP); d, cooked rice grains (HP). Arrows refer to the following structures: (cr), crack; (ho), hollow. The bar indicates $1 \mathrm{~mm}$. 
gestibility for high-amylose rice (Hamasari) was observed. For HP-treated samples, reducing sugar content after 60 min digestion was $1.12-1.27$ times higher than that of non-HP sample. The result indicated that HP-treated rice was more easily digested. It was reported that water penetrates to the deep part of the rice grain after HP treatment. $\left.{ }^{6}\right)$ This suggested that HP treatment injures the microstructure of the rice grains to some extent, which allows water to penetrate to the inner part and makes starch easier to digest.

The degree of gelatinization of starch in cooked rice is listed in Table 2. The degree of starch gelatinization of just-cooked rice is usually $94-96 \% .^{33)}$ Though our cooked rice was lyophilized, Milky Queen and Koshihikari showed a high degree of gelatinization. HP treatment resulted in a higher degree of gelatinization than for non-HP samples, probably due to the high penetration of water
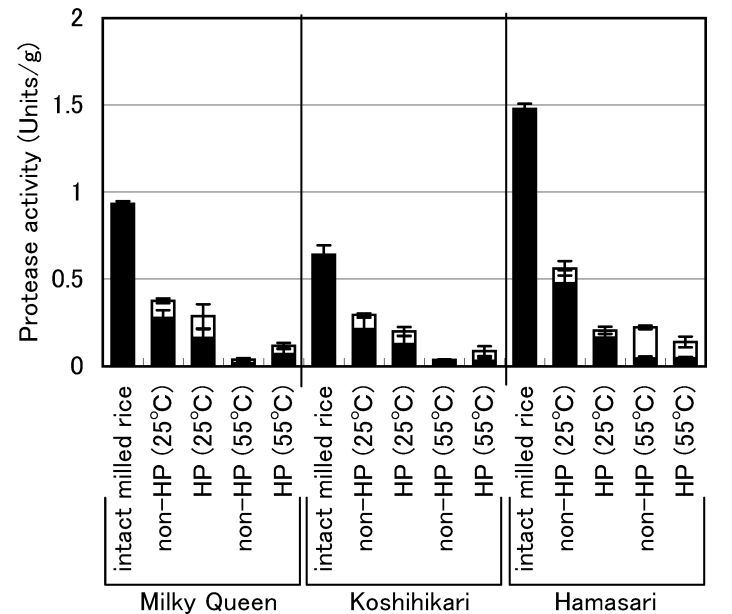

Fig. 6. Protease activity in the rice grains and soaking solution.

$\square$, rice grains; $\square$, soaking solution.

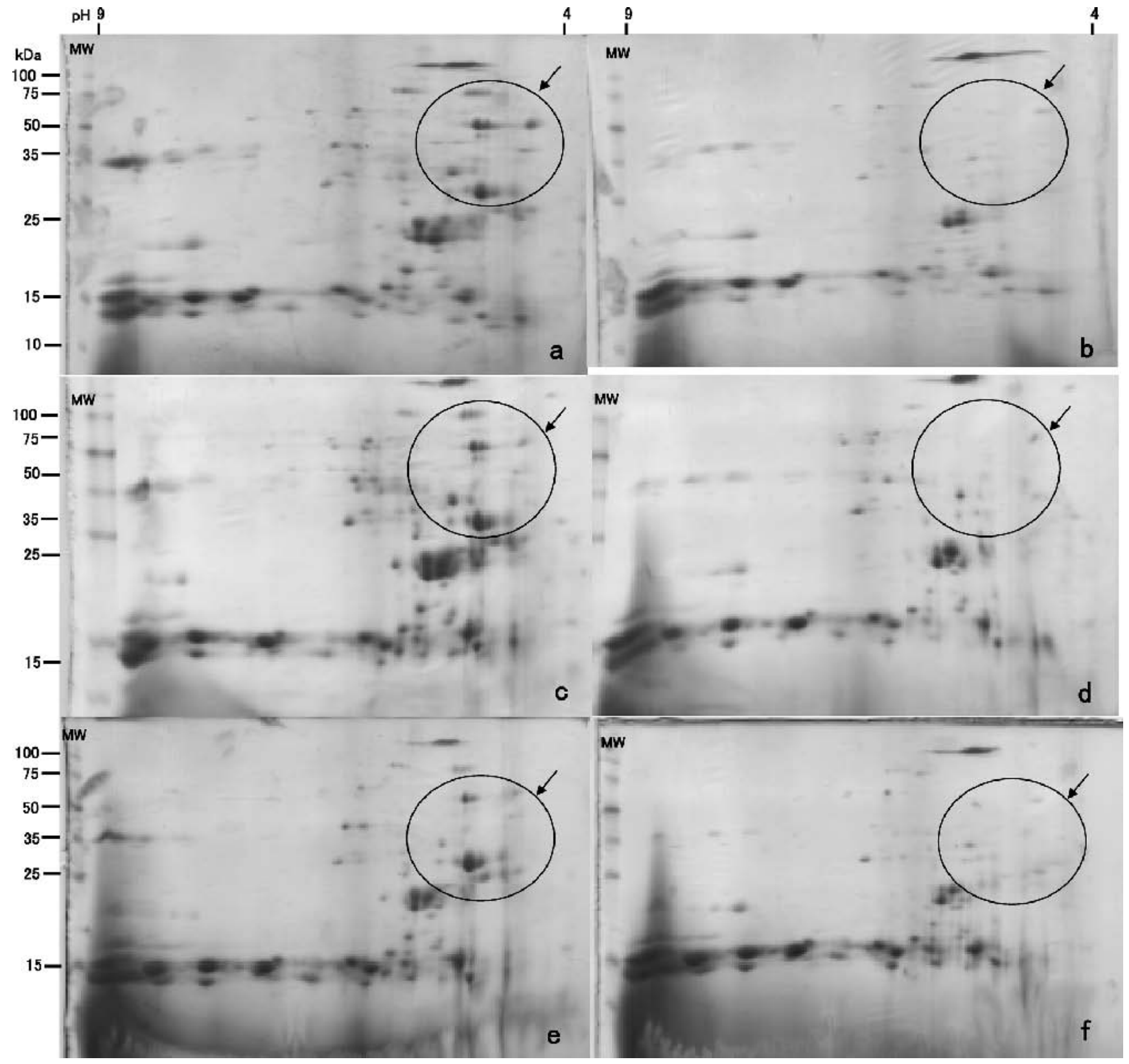

Fig. 7. Analysis by 2D-PAGE of water soluble proteins from rice endosperm.

The proteins were detected by CBB staining. Left to right, isoelectric focusing for the first dimension; top to bottom, SDS-PAGE for the second dimension. a, Milky Queen (non-HP); b, Milky Queen (HP); c, Koshihikari (non-HP); d, Koshihikari (HP); e, Hamasari (non-HP); f, Hamasari (HP). Arrows: areas where protein spots decreased or disappered. 
Table 3. Free amino acid contents of high pressure treated raw rice samples (mg/100 $\mathrm{g}$ flour sample, dry basis).

\begin{tabular}{|c|c|c|c|c|c|c|c|c|c|c|c|c|}
\hline \multirow{3}{*}{ Components } & \multicolumn{4}{|c|}{ Milky Queen } & \multicolumn{4}{|c|}{ Koshihikari } & \multicolumn{4}{|c|}{ Hamasari } \\
\hline & \multicolumn{2}{|c|}{$25^{\circ} \mathrm{C}$} & \multicolumn{2}{|c|}{$55^{\circ} \mathrm{C}$} & \multicolumn{2}{|c|}{$25^{\circ} \mathrm{C}$} & \multicolumn{2}{|c|}{$55^{\circ} \mathrm{C}$} & \multicolumn{2}{|c|}{$25^{\circ} \mathrm{C}$} & \multicolumn{2}{|c|}{$55^{\circ} \mathrm{C}$} \\
\hline & non-HP & $\mathrm{HP}$ & non-HP & HP & non-HP & HP & non-HP & HP & non-HP & $\mathrm{HP}$ & non-HP & HP \\
\hline Asp & $9.37^{\mathrm{a}}$ & $9.84^{\mathrm{b}}$ & $10.00^{b}$ & $9.69^{\mathrm{b}}$ & $5.89^{\mathrm{a}}$ & $6.18^{\mathrm{b}}$ & $5.65^{\mathrm{c}}$ & $5.72^{\mathrm{c}}$ & $19.84^{\mathrm{a}}$ & $18.54^{\mathrm{a}}$ & $18.84^{\mathrm{a}}$ & $19.00^{\mathrm{a}}$ \\
\hline Thr & $0.60^{\mathrm{a}}$ & $0.79^{\mathrm{a}}$ & $0.69^{\mathrm{a}}$ & $0.75^{\mathrm{a}}$ & $0.38^{\mathrm{a}}$ & $0.58^{\mathrm{a}}$ & $0.49^{\mathrm{a}}$ & $0.52^{\mathrm{a}}$ & $1.31^{\mathrm{a}}$ & $1.38^{\mathrm{a}}$ & $1.69^{\mathrm{a}}$ & $1.32^{\mathrm{a}}$ \\
\hline Ser & $2.85^{\mathrm{a}}$ & $3.20^{\mathrm{b}}$ & $3.09^{\mathrm{b}}$ & $2.99^{\mathrm{b}}$ & $1.35^{\mathrm{a}}$ & $1.77^{\mathrm{b}}$ & $1.42^{\mathrm{a}}$ & $1.54^{\mathrm{a}}$ & $6.37^{\mathrm{a}}$ & $6.39^{\mathrm{a}}$ & $6.30^{\mathrm{a}}$ & $6.28^{\mathrm{a}}$ \\
\hline Glu & $7.56^{\mathrm{a}}$ & $7.31^{\mathrm{a}}$ & $7.14^{\mathrm{b}}$ & $8.33^{\mathrm{c}}$ & $7.62^{\mathrm{a}}$ & $7.07^{\mathrm{b}}$ & $6.65^{\mathrm{c}}$ & $7.78^{\mathrm{a}}$ & $15.41^{\mathrm{a}}$ & $13.70^{\mathrm{b}}$ & $13.05^{\mathrm{c}}$ & $16.38^{\mathrm{a}}$ \\
\hline Glu $\mathrm{NH}_{2}$ & $10.74^{\mathrm{a}}$ & $11.93^{\mathrm{b}}$ & $11.93^{\mathrm{c}}$ & $10.96^{\mathrm{a}}$ & $2.23^{\mathrm{a}}$ & $3.20^{\mathrm{b}}$ & $2.25^{\mathrm{a}}$ & $2.62^{\mathrm{c}}$ & $47.61^{\mathrm{a}}$ & $37.23^{\mathrm{b}}$ & $45.35^{\mathrm{a}}$ & $46.42^{\mathrm{a}}$ \\
\hline Gly & $1.03^{\mathrm{a}}$ & $1.77^{\mathrm{b}}$ & $1.24^{\mathrm{a}}$ & $1.66^{\mathrm{c}}$ & $0.57^{\mathrm{a}}$ & $1.18^{\mathrm{b}}$ & $0.73^{\mathrm{c}}$ & $1.04^{\mathrm{d}}$ & $1.19^{\mathrm{a}}$ & $2.37^{\mathrm{a}}$ & $1.43^{\mathrm{a}}$ & $2.24^{\mathrm{a}}$ \\
\hline Ala & $0.06^{\mathrm{a}}$ & $0.06^{\mathrm{a}}$ & $0.06^{\mathrm{a}}$ & $0.06^{\mathrm{a}}$ & $0.02^{\mathrm{a}}$ & $0.03^{\mathrm{a}}$ & $0.02^{\mathrm{a}}$ & $0.02^{\mathrm{a}}$ & $5.18^{\mathrm{a}}$ & $5.82^{\mathrm{a}}$ & $5.22^{\mathrm{a}}$ & $5.20^{\mathrm{a}}$ \\
\hline GABA & $7.82^{\mathrm{a}}$ & $9.02^{\mathrm{b}}$ & $9.25^{\mathrm{b}}$ & $8.15^{\mathrm{c}}$ & $3.14^{\mathrm{a}}$ & $4.49^{b}$ & $3.87^{\mathrm{c}}$ & $3.61^{d}$ & $7.36^{\mathrm{a}}$ & $8.72^{\mathrm{a}}$ & $8.82^{\mathrm{a}}$ & $7.51^{\mathrm{a}}$ \\
\hline Total amino acids & 40.04 & 43.92 & 43.40 & 42.59 & 21.21 & 24.50 & 21.09 & 22.86 & 104.26 & 94.16 & 100.70 & 104.35 \\
\hline
\end{tabular}

Different letters in the same column indicate significant difference $(p<0.05) .(n=3)$.

into the rice grains brought about by HP treatment.

The effect of HP treatment on the structure of the inner part of the rice grains was investigated by NMR micro imaging. Figure 5 shows the MR slice images at the central part of raw and cooked grains of Koshihikari. Soaked raw rice grains had cracks filled with penetrated water, but no difference was observed between non-HP (Fig. 5a) and HP-treated samples (Fig. 5b). As for cooked grains, internal hollows were found in non-HP grains (Fig. 5c) but not in HP-treated samples (Fig. 5d). It was reported that internal hollows were observed more in cooked nonwaxy rice grains than in waxy rice, which contained only small rounder hollows. ${ }^{34)}$ Cultivars with a higher final hollow ratio in the cooked grains generally showed a higher peak in RVA, which was reflected in rigidity to starch granules. ${ }^{34)}$ In this study, HP-treated rice had a lower peak in RVA than non-HP rice (Table 1). Yamazaki et al. ${ }^{\text {o) }}$ demonstrated that water penetrated to the deep part of the grain after HP-treatment, which suggested that the HP treatment allows water to penetrate to the inner part of the rice grain and makes the starch granules more swollen and fragile than the normal soaking process under ordinary pressure. This suggestion is supported by the results that HP-treated starch granules were gelatinized at a lower peak viscosity than those of normally soaked samples (Table 1), and HP-treated samples showed a higher degree of gelatinization (Table 2). The starch granules in the inner part of the HP-treated grains may be more expanded than those in the normally soaked grains and invade most of the hollows at the end of cooking like in waxy rice.

Figure 6 shows the change in protease activities with the soaking and/or HP treatment. The intact milled rice grains showed the highest enzyme activity, but the activity decreased with the soaking. When the soaking temperature was high, the activity decreased. HP treatment also made the protease activity decrease. It has been reported that protease was located in the outer layer of the rice grain. ${ }^{35}$ In our study, protease activity decreased with soaking at high temperature and/or HP treatment.

Table 2 shows the total protein and insoluble protein contents. Total protein content was 7.49-7.59\% in Milky Queen, 5.82-5.97\% in Koshihikari and 7.83-8.01\% in Hamasari, and no definite difference was observed between non-HP and HP. The ratio of insoluble proteins to total protein increased in the order of intact rice, non-HP rice and HP treated rice. Allergenic proteins of rice were found in a globulin ${ }^{36)}$ and albumin ${ }^{37)}$ fraction. In our study, HP-treatment denatured soluble proteins and made them water insoluble.

Figure 7 shows 2D-PAGE patterns of water soluble protein. The protein spots corresponding to non-HP and HP were clearly observed in the stained gel. In HP, several protein spots disappeared and some other protein spots markedly decreased their staining intensity compared with non-HP. Rice proteins are classified by their solubility. The greater part of water soluble proteins are estimated to be albumin, which is located in aleurone cells. ${ }^{10)}$ Thus, it was estimated that HP treatment would be effective to denature the water soluble protein, albumin, because it was located in the outer layer of the milled rice.

Table 3 summarizes the free amino acid contents. Although free amino acid content was higher in Hamasari compared to the other two cultivars, no definite difference was observed between non-HP and HP treated samples. In the case of Milky Queen and Koshihikari, some free amino acids increased with the soaking at $55^{\circ} \mathrm{C}$ or $\mathrm{HP}$ treatment. This result was similar to that reported by Kinefuchi et al. ${ }^{5}$ Hamasari had the highest amounts of free amino acids, followed by Milky Queen and Koshihikari. The result suggested that the amount of total and reducing sugar were not related to amylose content. From the results, it was shown that some amino acids increased in HP treatment, though protease activity decreased in presoaking and HP treatment. The preferential proteolysis by HP treatment was reported. ${ }^{38)}$ The rate of protein hydrolysis increased as the pressure increased. ${ }^{39)}$ This suggested that protein was denatured by the HP treatment, and therefore proteolysis increased. From the results, it was concluded as follows: (1) The hydrolytic enzymes, optimum temperature of which were high, functioned during the presoaking. (2) Rice proteins were decomposed to increase the free amino acids during the HP treatment. And one after another, some proteases were damaged. (3) Some free amino acid such as serine, glycine and GABA increased with soaking temperature and/or HP treatment. This means that high temperature presoaking and HP treatment can be effective for the improvement of taste, nutrition and bio-functionality such as prevention of hypertension, which was reported for GABA of cooked rice. 
We appreciate the assistance of the staff of the Echigo Seika Co., Ltd. for preparation of pre-soaked and/or HP samples.

\section{REFERENCES}

1 ) R. Hayashi: Progress of high pressure use. in High-Pressure Bioscience and Food Science, R. Hayashi ed., San-Ei Pub., Kyoto, pp. 1-17 (1993).

2 ) A. Yamazaki and A. Sasagawa: Development of rice food products produced by high-pressure treatment. Nippon Nogeikagaku Kaishi, 45, 526-532 (1998).

3 ) E. Arai and M. Watanabe: Improving the cooking properties of Indica rice grains by pressurization and enzymatic treatments. Nippon Shokuhin Kogyo Gakkaishi, 41, 619-626 (1994).

4 ) T. Kato, E. Katayama, S. Matsubara, Y. Omi and T. Matsuda: Release of allergenic proteins from rice grains induced by high-hydrostatic pressure. J. Agric. Food Chem., 48, 31243129 (2000).

5 ) M. Kinefuchi, M. Sekiya, A. Yamazaki and K. Yamamoto: Accumulation of GABA in brown rice by high pressure treatment. Food Sci. Technol. Res., 46, 323-328 (1999).

6 ) A. Yamazaki, M. Kinefuchi, K. Yamamoto and A. Yamada: Physical properties and fine structure of grains of highpressure-treated rice after cooking. Rev. High Pressure Sci. Technol., 5, 168-178 (1996).

7 ) K. Ohtsubo, M. Nakahara and T. Iwasaki: Utilization suitabilities of new endosperm characters of rice stains. Nippon Shokuhin Kogyo Gakkaishi, 35, 587-594 (1988).

8 ) H. Toyoshima, H. Okadome, K. Ohtsubo, M. Suto, N. Horisue, O. Inatsu, A. Narizuka, M. Aizaki, T. Okawa, N. Inouchi and H. Fuwa: Cooperative test on the small-scale rapid method for the gelatinization properties test of rice flours with a Rapid-Visco-Analyser (RVA). Nippon Shokuhin Kogyo Gakkaishi, 44, 579-584 (1997).

9 ) H. Okadome, M. Kurihara, O. Kusuda, H. Toyoshima, J. il Kim, K. Shimotsubo, T. Matsuda and K. Ohtsubo: Multiple measurements of physical properties of cooked rice grains with different nitrogenous fertilizers. Jpn. J. Crop Sci., 68, 211-216 (1999).

10) K. Tanaka: Protein bodies and aleurone particles in rice grains. Nippon Nogeikagaku Kaishi, 56, 39-47 (1982).

11) M. Tajima, T. Horino, M. Maeda and J.R. Son: Maltooligosaccharides extracted from outer-layer of rice grain. Nippon Shokuhin Kogyo Gakkaishi, 39, 857-861 (1992).

12) B.O. Juliano: A simplified assay for milled-rice amylose. $\mathrm{Ce}$ real Sci. Today, 16, 334-338, 340-360 (1971).

13) K. Kainuma: The method of phenol-sulphuric acid. in Shokuhin bunseki hou, Nippon Shokuhin Kougyo Gakkai, ed., Kourin Pub., Tokyo, pp. 189-191 (1982).

14) K. Kainuma: The method of Somogyi-Nelson. in Shokuhin bunseki hou, Nippon Shokuhin Kougyo Gakkai, ed., Kourin Pub., Tokyo, pp. 170-172 (1982).

15) T. Saikusa, T. Horino and Y. Mori: Distribution of free amino acids in the rice kernel and kernel fractions and the effect of water soaking on the distribution. J. Agric. Food Chem., 42, 1122-1125 (1994).

16) E.P. Palmiano and B.O. Juliano: Biochemical changes in the rice grain during germination. Plant Physiol., 49, 751-756 (1972).

17) Y. Imai, S. Tokutake, N. Yamaji and M. Suzuki: An improved method for measuring of $\alpha$-glucosidase activity in rice koji. $J$. Brew. Soc. Jpn, 92, 296-302 (1997).

18) H. Iwata, S. Iwase, K. Takahama, H. Matsuura, T. Itani and I. Aramaki: Relationship between $\alpha$-glucosidase activity and physical and chemical properties of rice. Nippon Shokuhin Kagaku Kogaku Kaishi, 48, 482-490 (2001).

19) R. Niihara and K. Miyoshi: Texture and starch digestibility of rice-gruels and cooked rice. Bull. Fac. Edu., Kochi Univ. Ser. 3, 9-14 (1997).
20) K. Kainuma, A. Matsunaga, M. Itagawa and S. Kobayashi: New enzyme system- $\beta$-amylase-pullulanase to determine the degree of gelatinization and retrogradation of starch or starch products. J. Jpn. Soc. Starch Sci, 28, 235-240 (1981).

21) A.K. Horigane, H. Toyoshima, H. Hemmi, W.M.H.G. Engelaar, A. Okubo and T. Nataga: Internal hollows in cooked rice grains (Oryza sativa cv. Koshihikari) observed by NMR micro imaging. J. Food Sci., 64, 1-5 (1999).

22) H. Hirano: Varietal differences of leaf protein profiles in mulberry. Phytochemistry, 21, 1513-1518 (1982).

23) P.H. O’Farrell: High resolution two-dimensional electrophoresis of proteins. J. Biol. Chem., 250, 4007-4021 (1975).

24) U.K. Laemmili: Cleavage of structural proteins during assembly of the head of bacteriophage T4. Nature, 227, 680-685 (1970).

25) S. Chikubu, S. Watanabe, T. Sugimoto, F. Sakai and Y. Taniguchi: Relation between palatability evaluations of cooked rice and physicochemical properties of rice. J. Jpn Soc. Starch Sci., 30, 333-341 (1983).

26) H. Mizukami, S. Hizukuri and Y. Takeda: Structures and pasting properties of starches from now characteristic rice cultivars. J. Appl. Glycosci., 43, 15-23 (1996).

27) C. Ohya and A. Kawabata: The structure and gelatinization properties of rice starch prepared from different varieties. Nippon Shokuhin Kogyo Gakkaishi, 40, 225-235 (1993).

28) S. Saito: Rice starch and rice powder as materials for food industry. J. Jpn. Soc. Starch Sci., 27, 295-313 (1980).

29) E. Maruyama, C. Nishi, Y. Miyata and T. Kajita: Studies on the cooking of rice (part 4) Change in amylase activity during cooking of rice. Kaseigaku Zasshi, 32, 253-258 (1981).

30) E. Maruyama: Enzymes producing oligosaccharides in the process of cooking rice. Nippon Kaseigaku Kaishi, 53, 431436 (2002).

31) M. Awazuhara, A. Nakagawa, J. Yamaguchi, T. Fujiwara, H. Hayashi, K. Hatae, M. Chino and A. Shimada: Distribution and characterization of enzymes causing starch degradation in rice (Oryza sativa cv. Koshihikari). J. Agric. Food Chem., 48, 245-252 (2000).

32) Y. Masui: Study on the properties of starch degradation enzymes in high-pressure treated rice. Iijima Mem. Found. Prom. Food Sci. Technol. Ann. Rep., 1999, 239-243 (1999).

33) A. Matsunaga, N. Ishida and K. Kainuma: Degree of gelatinization of starch during the cooking process of rice. Nippon Shokuhin Kogyo Gakkaishi, 32, 797-803 (1985).

34) A.K. Horigane, W.M.H.G. Engelaar, H. Toyoshima, H. Ono, M. Sakai, A. Okubo and T. Nagata: Differences in hollow volumes in cooked rice grains with various amylose contents as determined by NMR micro imaging. J. Food Sci., 65, 408-412 (2000).

35) S. Barber: Milled rice and changes during aging. in Rice Chemistry and Technology, D.F. Houston ed., Am. Assoc. Cereal Chem., St. Paul, MN, pp. 215-263 (1972).

36) G.G. Limas, M. Salinas, I. Moneo, S. Fischer, L.B. Wittmann and E. Mendez: Purification and characterization of ten new rice $\mathrm{NaCl}$-soluble proteins: Identification of four proteinsynthesis inhibitors and two immunoglobulin-binding protein. Planta, 181, 1-9 (1990).

37) T. Matsuda, M. Sugiyama, R. Nakamura and S. Torii: Purification and properties of an allergenic protein in rice grain. Agric. Biol. Chem., 52, 1465-1470 (1988).

38) M. Okamoto and R. Hayashi: Application of high pressure to preferential enzymatic degradation of $\beta$-lacto-globulin in bovine milk whey. in Pressure-processed Food, R. Hayashi ed., San-Ei Pub., Kyoto, pp. 59-67 (1990).

39) K. Hayashi, S. Takahashi, H. Asano and R. Hayashi: Effect of pressure on the acid hydrolysis of proteins and polysaccharides. in Pressure-processed Food, R. Hayashi ed., San-Ei Pub., Kyoto, pp. 277-288 (1990). 


\section{超高圧処理と浸漬が炊飯米の品質に及ぼす影響}

山倉美穂 ${ }^{1}$, 原口和朋 ${ }^{2}$, 岡留博司 ${ }^{2}$, 鈴木啓太郎 ${ }^{2}$, チャンチウェン ${ }^{1,2}$, 堀金明美 ${ }^{2}$, 吉田 充 $^{2}$, 本間清一 ${ }^{1}$, 笹川秋彦 ${ }^{3}$, 山㟝 涁 $^{3}$, 大坪研一1,2

${ }^{1}$ お茶の水女子大学大学院人間文化研究科

（112-8610 東京都文京区大塚 2-1-1)

2 独立行政法人食品総合研究所

（305-8642 つくば市観音台 2-1-12）

3 越後製菓株式会社総合研究所

（947-0102 小千谷市高梨町 1003-1）

超高圧処理は, 食品産業における新しい技術であり, 米飯にも応用されている，日本では通常，炊飯前に浸漬 を行う。浸漬もまた炊飯米の性状に影響を及ぼす一要因 である，夜に洗米・浸漬を行い，翌朝に炊飯を開始する ということもしばしば行われる。本報告では，25ㄷ いは $55^{\circ} \mathrm{C}$ で 30 分間の予備浸漬を行い, その後 $400 \mathrm{MPa}$ で 10 分間の超高圧(HP)処理を行った後で一晚の浸漬を続 け, 予備浸漬温度と HP 処理の有無が米に与える物理的, 化学的影響を調べた。 その結果, 糊化特性では, 浸漬操 作により最高粘度が増加し, 食味が向上する可能性が示 唆された。また, HP 処理により, 糖含量の増加が認めら れ，また炊飯米粒内部の構造の変化も認められた。また， 炊飯米の糊化度が増し, 消化性が向上した。また, HP 処 理区において, 純水可溶性タンパク質の変性がみられた。 呈味成分である遊離アミノ酸は, 予備浸漬温度, HP 処理 に伴って増加していた，以上のことから，超高圧処理は 米加工に利用でき, 新たな食味改善技術の一つとしての 可能性が期待できると考えられる. 